\title{
Effect of Zinc, Selenium and their Combination on Cadmium- Induced Oxidative Stress in Rat Kidney-A Molecular Study
}

\author{
Safaa I. Khater, Hamad A. ELsaadawy, Shrouk A. El-Basyoni* \\ Biochemistry Department, Faculty of Veterinary Medicine, Zagazig University, 44511, Egypt
}

\begin{abstract}
Cadmium $(\mathrm{Cd})$ is considered as a very toxic heavy metal which transfers to the body through many routes as food, water and air. Zinc $(\mathrm{Zn})$ and selenium $(\mathrm{Se})$ have a great role in alleviation of Cd toxicity in kidneys. This study aimed to look into the interaction between $\mathrm{Cd}, \mathrm{Zn}$, Se and their effects on gene expression of the antioxidant enzymes in the kidneys of rats. Fifty male adult albino rats were divided into five groups $(n=10)$ that received orally the following doses daily for one month: Group I: control group received normal saline, Group II: received $2 \mathrm{mg} / \mathrm{kg}$ BW $\mathrm{CdCl}_{2}$, Group ПI: was administered $2 \mathrm{mg} / \mathrm{kg} \mathrm{CdCl}_{2}$ and $2 \mathrm{mg} / \mathrm{kg} \mathrm{ZnCl}$, Group IV: received 2 $\mathrm{mg} / \mathrm{kg} \mathrm{CdCl}{ }_{2}$ and $0.23 \mathrm{mg} / \mathrm{kg} \mathrm{Na} \mathrm{SeO}_{3}$, and Group V: received $2 \mathrm{mg} / \mathrm{kg} \mathrm{CdCl} 2,2 \mathrm{mg} / \mathrm{kg} \mathrm{ZnCl}_{2}$ and $0.23 \mathrm{mg} / \mathrm{kg} \mathrm{Na}_{2} \mathrm{SeO}_{3}$ ). The gene expression levels of SOD1, CAT, GPx, HSP70 and MT1 were assessed in the kidneys; treatment with Cd lowered the expression of antioxidant enzymes (SOD1, CAT, and GPx) and increased the expression level of HSP70 and MT1. Only partial ameliorative effects on the oxidative stress caused by $\mathrm{Cd}$ in the kidney have been observed with $\mathrm{Se}$ or $\mathrm{Zn}$ supplementation during exposure to $\mathrm{Cd}$, while the co-treated with $\mathrm{Se}$ and $\mathrm{Zn}$ revealed better protection against the observed oxidative stress in kidney.
\end{abstract}

Keywords: Zinc, Selenium, Cadmium, Oxidative Stress, Gene Expression, Metallothionine

\section{Introduction}

World Health Organization recorded that cadmium $(\mathrm{Cd})$ is a very dangerous for public health [1]. Cd enters in the soil, ground and drinking water via agricultural and industrial activities. Cd has high soluble nature and Plants absorb its compounds easily from soil resulting in accumulation in human and animal feed [2]. So, humans can easily expose to $\mathrm{Cd}$ through the diet [3]. Vegetables and cereals contain the highest amount of $\mathrm{Cd}$ present in the diet [4]. Smoking, occupational exposure and house dust are also other sources of $\mathrm{Cd}$ exposure [5]. Cd induces oxidative stress and causes damage to the cell through; competition with redox-active metals, depletion of antioxidant metabolites, exhaustion of antioxidant enzymes and interfering with electron transport chain which lead to damage of mitochondria and cell apoptosis [6].

Enzymatic and non-enzymatic defense mechanisms are involved together in protection of cells from oxidative stress caused by $\mathrm{Cd}$ [7]. The enzymatic antioxidants include superoxide dismutase (SOD), catalase, glutathione peroxidase (GPx) and esterase [8], and non-enzymatic include molecules such as glutathione $(\mathrm{GSH})$ and trace metals such as selenium and zinc [9].
Zinc is an essential metal involved in treatment of harmful effect caused by heavy metals specially $\mathrm{Cd}$. Zinc has the same chemical and physical properties of $\mathrm{Cd}$, so it competes with $\mathrm{Cd}$ in the enzyme binding sites [10]. Zinc also induces the metallothionein (MT) synthesis, which helps to detoxify Cd by binding it [11]. Moreover, recent studies suggested that intake of zinc can ameliorate Cd induced oxidative stress [12], due to zinc is a cofactor of copper zinc- superoxide dismutase enzyme.

Selenium (Se) plays an important role in the intra-cellular antioxidant system as a structural component of the selenoprotein enzymes, including glutathione peroxidase. The selenoprotein enzymes catalyze the reduction of hydro peroxidases to less toxic products, thereby protecting cells against oxidative stress [13]. Many studies approved that treatment with selenium during $\mathrm{Cd}$ exposure decreased the harmful effect of cadmium toxicity in kidney and other organs. Selenium contributes to the antioxidant defense system as a cofactor of the glutathione peroxidase (GPx) enzyme, which has a significant role in alleviation of $\mathrm{Cd}$ toxicity and improving the antioxidant capacity of the host [14]. Selenium 
also can enhance cadmium detoxification through forming inactive complex with cadmium and so help to eliminate it [15]. The aim of this study was to evaluate the interaction between $\mathrm{Cd}, \mathrm{Zn}$ and $\mathrm{Se}$ and their effects on gene expression of the antioxidant enzymes in the kidneys of rats

\section{Material and Methods}

\section{Animal Management}

Each group of rats was housed in separate cage. The room of the experiment was maintained at temperature $24 \pm 3{ }^{\circ} \mathrm{C}$ and relative humidity at $70 \%$ and a $12 \mathrm{~h}$ light $/ 12 \mathrm{~h}$ dark cycle was applied. The animals were given a standard laboratory pellet feed and purified drinking ad libitum. Oral dosing was done by number of gauge oral feeding needle.

\section{Chemicals}

Cadmium chloride $(\mathrm{CdCl} 2)$ was purchased from Merck (Darmstadt, Germany), a vial of sterilized cadmium chloride powder contains 100 gm. of cadmium chloride active ingredient. Zinc chloride $(\mathrm{ZnCl} 2)$ was obtained from Sigma Aldrich. (St. Louis, MO, USA), a vial of sterilized zinc chloride powder contains $500 \mathrm{gm}$. of zinc chloride active ingredient. Sodium selenite (Na2Seo3) was purchased from Basingstoke Hampshire, England; a vial of sterilized sodium selenite powder contains $100 \mathrm{gm}$ of sodium selenite active ingredient.

\section{Animal Selection and Grouping}

Fifty male adult albino rats were used in the experimental investigation of this study. All experimental animals after acclimatization for two weeks before treatment, were divided into five groups $(n=10)$ : Group I: control group received normal saline, Group II: received $\left(\mathrm{CdCl}_{2}\right)$, at a dose level of $(2 \mathrm{mg} / \mathrm{kg})$, Group $\Pi$ I: received $\left(\mathrm{CdCl}_{2}\right)$ and $\left(\mathrm{ZnCl}_{2}\right)$, at a dose level of $(2 \mathrm{mg} / \mathrm{kg} \& 2 \mathrm{mg} / \mathrm{kg})$ respectively , Group IV: received $\left(\mathrm{CdCl}_{2}\right)$ and $\left(\mathrm{Na}_{2} \mathrm{SeO}_{3}\right)$, at a dose level of $(2 \mathrm{mg} / \mathrm{kg} \& 0.23 \mathrm{mg} / \mathrm{kg})$ respectively and Group V: received $\left(\mathrm{CdCl}_{2}\right)$, $\left(\mathrm{ZnCl}_{2}\right)$ and $\left(\mathrm{Na}_{2} \mathrm{SeO}_{3}\right)$, at a dose level of (2 $\mathrm{mg} / \mathrm{kg} \& 2 \mathrm{mg} / \mathrm{kg} \& 0.23 \mathrm{mg} / \mathrm{kg}$ ) respectively. Intra-gastric tubes were used for the treatment of all animals daily for one month. Then the animals were killed and kidney tissues were collected for biochemical and molecular analysis.

\section{Sampling}

Immediately after sacrifying, kidney tissue was taken divided into two parts, one for homogenization and estimation levels tissue residue in kidney, and the other was wrapped in aluminum foil and put immediately in liquid nitrogen container to make snap-freezing of tissue and minimize the action of endogenous RNase, for real time-PCR analysis and estimation of gene expression levels of selected genes in kidney tissues.

\section{Determination of the tissue residue of $\mathrm{Cd}, \mathrm{Zn}$ and Se}

The samples were prepared according to Nasr et al., [16]. Briefly, one gram of rat kidney tissues was transferred to a clean screw capped glass bottle and digested with $10 \mathrm{ml}$ of digesting solution (nitric acid/ per chloric acid 4:1) for 4 hours at room temperature, followed by heating at $40-45^{\circ} \mathrm{C}$ for one hour in water bath, then temperature raised to $75^{\circ} \mathrm{C}$ until the end of digestion. After cooling at room temperature, the digest was diluted to $20 \mathrm{ml}$ with deionized water and filtered through $0.45 \mu \mathrm{m}$ Whatman filter paper. The filtrate was kept in refrigerator till analysis. For the preparation of the blank solution, $10 \mathrm{ml}$ solution of nitric/ per chloric acid (4:1) were put in a screw capped glass bottle and exposed to the same previous procedure [16]. Quantitative determination of cadmium, zinc, and selenium residues was conducted by using thermo Jarrell Ash Atomic Absorption Spectrophotometer, in Central Laboratory of Faculty of Veterinary Medicine, Zagazig University. The concentrations of metal (ppm) in the examined samples were calculated according the following equation:

Concentration of metal in samples= $\mathrm{AXB} \div \mathrm{W}$, where $\mathrm{A}=$ metal concentration $(\mathrm{ppm})$ in the prepared samples from the digital scale reading of Atomic Absorption Spectrophotometer, $\mathrm{B}=$ the final volume of the prepared samples, $\mathrm{W}=$ weight of samples in gram.

\section{Molecular analysis}

The total RNA was extracted from kidney tissue by using RNeasy Mini Kits (Qiagen, Cat. No. 74104), following the manufacturer instructions. The extracted RNA was quantified and qualified by using Nano Drop ${ }^{\circledR}$ 
ND-1000 Spectrophotometer, Nano Drop Technologies, Wilmington, Delaware USA. The purity of RNA was checked and ranged between 1.8 and 2.1, demonstrating good quality of the RNA. First strand cDNA was synthesized using Revert Aid TM H Minus (Fermentas, life science, Pittsburgh, PA, USA), according to manufacturer instructions. One $\mu 1$ of total cDNA was mixed with $12.5 \mu \mathrm{l}$ of 2x SYBR_ Green PCR mix with ROX from Bio-Rad, $5.5 \mu$ of D.D water and $0.5 \mu \mathrm{l}$ of each forward and reverse primers for the measured genes. The normalization assessed by using $\beta$-actin gene as a control. Primer sequences of rat SOD1, CAT, GPx, HSP70 and $\beta$-actin were obtained from the published sequences of [17], and for MT1 from the published sequences of [18]. (Table1). According to Livak and Schmittgen [19] the $\left(2^{-\Delta \Delta c t}\right)$ method was used to calculate fold change for quantification of mRNA levels.

Table 1: Primers sequences for qRT-PCR

\begin{tabular}{|c|c|c|c|}
\hline Gene & Oligonucleotide sequence & $\begin{array}{c}\text { Annealing } \\
\text { temperature }\end{array}$ & $\begin{array}{l}\text { Number of } \\
\text { cycle }\end{array}$ \\
\hline SOD1 & $\begin{array}{l}\text { F 5'- ACACAAGGCTGTACCACTGC -3' } \\
\text { R 5'- CCACATTGCCCAGGTCTCC -3' }\end{array}$ & 58.5 & 40 \\
\hline CAT & $\begin{array}{l}\text { F5'- TGCCGTCCGATTCTCCACAG -3' } \\
\text { R 5'- TCCCACGAGGTCCCAGTTAC -3' }\end{array}$ & 58.5 & 40 \\
\hline GSH-Px & $\begin{array}{l}\text { F 5'- GTCCACCGTGTATGCCTTCTCC-3' } \\
\text { R 5'- TCTCCTGATGTCCGAACTGATTGC -3' }\end{array}$ & 58.5 & 40 \\
\hline HSP70 & $\begin{array}{l}\text { F 5'- ATCTCCTGGCTGGACTCTAACA -3' } \\
\text { R 5'- CACCCATCTGTCTCCTAGATCA -3' }\end{array}$ & 58.5 & 40 \\
\hline MT1 & $\begin{array}{l}\text { F 5'- GCGTCACCACGACTTCAAC -3' } \\
\text { R 5'- GTCACATCAGGCACAGCAC -3' }\end{array}$ & 60 & 40 \\
\hline B-actin & $\begin{array}{l}\text { F 5'- ACTATCGGCAATGAGCGGTTCC -3' } \\
\text { R5'- CTGTGTTGGCATAGAGGTCTTTACG 3' }\end{array}$ & 58.5 & 40 \\
\hline
\end{tabular}

\section{Results and Discussion}

\section{Tissue residue}

\section{Cadmium concentration in kidney tissues}

Our results come in agreement with Zabulyte et al., [20] who confirmed that, the highest levels of $\mathrm{Cd}$ accumulation in rats found in kidney and $\mathrm{Cd}$ can induce multiple renal injuries. Data presented in Table (2) showed that there was a significant increase $(p<.05)$ in the concentration of kidney cadmium in the $(\mathrm{Cd}),(\mathrm{Cd}$ and $\mathrm{Zn}),(\mathrm{Cd}$ and $\mathrm{Se})$ and $(\mathrm{Cd}, \mathrm{Zn}$ and $\mathrm{Se})$ treated groups in comparison to control group, this result come with the result obtained by Štajn et al., [21]. But we found that, there was a significant decrease in $\mathrm{Cd}$ level in kidney tissues in groups $\Pi I$ and $\mathrm{V}$ treated with $\mathrm{Zn}$ and combined $\mathrm{Zn} \& \mathrm{Se}$, than that treated with $\mathrm{Cd}$ only, this may be due to that, $\mathrm{Zn}$ and Se act as antagonist to $\mathrm{Cd}$, Brzóska and MoniuszkoJakoniuk [22] mentioned that, Cd can interact with zinc and selenium during absorption, distribution, and excretion. $\mathrm{Cd}$ also interferes with functions of these elements. The antagonistic effect between $\mathrm{Zn}$ and $\mathrm{Cd}$ has approved that, $\mathrm{Cd}$ is an antimetabolite of $\mathrm{Zn}$.

\section{Zinc concentration in kidney tissues}

As shown in Table (2) the concentration of zinc in kidney tissues was significantly decreased $(\mathrm{p}<.05)$ in $(\mathrm{Cd})$ treated group in comparison to control group because of the similarity between zinc and cadmium in their chemical and physical characters so they compete at the active site of the enzyme as suggested by [23]. While, the conc. of zinc is significantly increased $(\mathrm{p}<.05)$ in $(\mathrm{Cd}$ and $\mathrm{Zn})$, $(\mathrm{Cd}$ and $\mathrm{Se})$ and $(\mathrm{Cd}, \mathrm{Zn}$ and $\mathrm{Se})$ treated groups in comparison to $\mathrm{Cd}$ treated group. The last result is in the same respect with other authors [22] who suggested that the exposure to $\mathrm{Cd}$ can modify $\mathrm{Zn}$ homeostasis by inducing the transport of $\mathrm{Zn}$ to target organs such as liver and kidneys.

\section{Selenium concentration in kidney tissues}

As shown in Table (2), there was a significant decrease $(p<.05)$ in kidney $\mathrm{Se}$ concentration in $\mathrm{Cd}$ treated group in comparison to control group this may be due to $\mathrm{Cd}$ exerts its harmful effect by a 
displacement of redox-active metals [6]. While, the concentration of Se in kidney was significantly increased in Se treated groups $(\mathrm{Cd}$ and $\mathrm{Se}$ ) and $(\mathrm{Cd}, \mathrm{Zn}$ and $\mathrm{Se}$ ) in comparison to $\mathrm{Cd}$ treated group. Accordingly, the increased concentration of Se in kidneys may be explained by forming $\mathrm{Cd}-\mathrm{Se}$ protein complexes $[24,25]$. The accumulation of both Se and $\mathrm{Cd}$ were increased in kidney after exposure to both elements and thus indicate that $\mathrm{Se}$ ameliorated the toxic effects of $\mathrm{Cd}$ and enhanced the accumulation of $\mathrm{Cd}$ and $\mathrm{Se}$ in kidney [26].

Table 2: Means \pm S.E. Cadmium, zinc and selenium concentration $(\mu \mathrm{g} / \mathrm{g})$ in kidney tissues

\begin{tabular}{cccccc}
\hline$(\boldsymbol{\mu g} \backslash \mathbf{g})$ & Control & Cd & Cd\&Zn & Cd\&Se & Cd\&Zn\&Se \\
\hline Cadmium & $0.55 \pm 0.01^{\mathrm{c}}$ & $5.31 \pm 0.21^{\mathrm{a}}$ & $4.13 \pm 0.11^{\mathrm{b}}$ & $4.94 \pm 0.09^{\mathrm{a}}$ & $0.50 \pm 0.04^{\mathrm{c}}$ \\
Zinc & $26.1 \pm 0.1^{\mathrm{b}}$ & $17.71 \pm 0.23^{\mathrm{d}}$ & $29 \pm 0.49^{\mathrm{a}}$ & $20.73 \pm 0.23^{\mathrm{c}}$ & $27.2 \pm 1.21^{\mathrm{ab}}$ \\
Selenium & $0.193 \pm 0.002^{\mathrm{ab}}$ & $0.173 \pm 0.003^{\mathrm{b}}$ & $0.175 \pm 0.002^{\mathrm{b}}$ & $0.208 \pm 0.009^{\mathrm{a}}$ & $0.214 \pm 0.01^{\mathrm{a}}$ \\
\hline
\end{tabular}

\section{Molecular biological analysis}

Superoxide dismutase expression in kidney tissues

Results showed in Table (3) revealed that SOD1 mRNA expression level in kidney decreased significantly in $\mathrm{Cd}$ treated group in comparison to control one, the inhibition of CuZnSOD expression is due to the competition between $\mathrm{Cd}$ and $\mathrm{Zn}$ in the enzyme binding sites as mentioned by Uchida et al., [27] and Hussain et al., [28]. Available data indicated that $\mathrm{Cd}$ has the ability to compete at the site of $\mathrm{Zn}$ in the $\mathrm{Cu} \mathrm{Zn}$ SOD molecule, resulting in inactive complex [29]. While the level of expression increased significantly in kidney of $\mathrm{Zn}$ treated groups $(\mathrm{Cd} \& \mathrm{Zn})$ and (Cd\&Zn\&Se), and thus confirmed that $\mathrm{Zn}$ acts as $\mathrm{Cd}$ antagonist and antioxidant against $\mathrm{Cd}$ induced oxidative stress [30, 31]. However, Se did not increase CuZn SOD expression in our finding; different results were reported before [32].

Glutathione peroxidase expression in kidney tissues

Data presented in Table (3) showed that there was down regulation in the GPx gene expression in the kidneys of $\mathrm{Cd}$ treated group in comparison to control group, this result has been explained before [33] as Se is a cofactor of GPx enzyme, and this decrease in GPx expression may be due to depletion of Se by
Cd. Other authors [34] mentioned that a chemical complex may be formed between $\mathrm{Cd}$ and $\mathrm{Se}$ at the active site of the enzyme, in addition to the competition for sulfur containing amino acids by Cd-metallothionein and GPx [35]. While there was up regulation in the GPx gene expression in the kidney of Se treated groups $(\mathrm{Cd} \& \mathrm{Se})$ and $(\mathrm{Cd} \& \mathrm{Zn} \& S e)$. This up regulation of GPx gene expression in Se treated groups may be attributed to increase the bioavailability of Se after co-treatment with sodium selenite and so increased GPx activity, as suggested before [36]. There was up regulation in the GPx gene expression in the kidney $\mathrm{Zn}$ treated groups $(\mathrm{Cd} \& \mathrm{Zn})$ and (Cd\&Zn\&Se), because zinc affects regulation of glutathione (GSH) synthesis [37].

\section{Catalase expression in kidney tissues}

Results showed in Table (3) revealed that there was significant decrease in catalase gene expression in the kidney of $\mathrm{Cd}$ treated group in comparison to control group, in agreement with our result, Jurczuk et al., [38] suggested that iron is an essential component of catalase enzyme and $\mathrm{Cd}$ decrease the level of iron in kidney. While there was a significant increase in catalase gene expression in kidney of $\mathrm{Zn}$ treated groups $(\mathrm{Cd} \& \mathrm{Zn})$, and $(\mathrm{Cd} \& \mathrm{Zn} \& S e)$ in comparison to $\mathrm{Cd}$ treated group, and these results are in the same line with Khan et al., [39], but it remained at the control value in kidney of Se treated groups. 
Table 3: Fold change of relative gene expression of antioxidant enzymes in kidney tissues

\begin{tabular}{llllll}
\hline Fold change & control & \multicolumn{1}{c}{ Cd } & \multicolumn{1}{c}{ Cd\&Zn } & Cd\&Se & Cd\&Zn\&Se \\
\hline SOD1 & $1.11 \pm 0.02^{\mathrm{b}}$ & $0.311 \pm 0.01^{\mathrm{c}}$ & $1.91 \pm 0.02^{\mathrm{a}}$ & $0.942 \pm 0.06^{\mathrm{b}}$ & $2.03 \pm 0.07^{\mathrm{a}}$ \\
GPX1 & $1.07 \pm 0.02^{\mathrm{b}}$ & $0.42 \pm 0.01^{\mathrm{c}}$ & $0.863 \pm 0.05^{\mathrm{b}}$ & $1.03 \pm 0.08^{\mathrm{b}}$ & $2.05 \pm 0.04^{\mathrm{a}}$ \\
CAT & $1.05 \pm 0.05^{\mathrm{a}}$ & $0.343 \pm 0.07^{\mathrm{b}}$ & $0.932 \pm 0.03^{\mathrm{a}}$ & $1.19 \pm 0.06^{\mathrm{a}}$ & $1.23 \pm 0.08^{\mathrm{a}}$ \\
\hline
\end{tabular}

Heat shock protien70 expression in kidney tissues

Data presented in Table (4) showed that there was up regulation in $\mathrm{HSP}_{70}$ gene expression in the kidney of $\mathrm{Cd}$ treated group in comparison to control group. Accordingly, Giffard et al., [40] and Han et al., [41] suggested that HSP70 is induced by a variety of different stressors, including heat, hypoxia, reactive oxygen species and toxic compounds, this may explain increasing the level of $\mathrm{HSP}_{70}$ in the kidney of rats which exposed to cadmium, while there was down regulation in $\mathrm{HSP}_{70}$ gene expression in the kidney of the group which given (Cd\&Zn\&Se) in comparison to $\mathrm{Cd}$ treated group. Agreement with our result, it is well documented also that Se [36] or $\mathrm{Zn} \mathrm{[42]} \mathrm{can} \mathrm{ameliorate} \mathrm{the} \mathrm{harmful}$ effects of $\mathrm{Cd}$ induced oxidative stress in different tissues.

\section{Metallothionien expression in kidney tissues}

Data presented in Table (4) showed that there was up regulation in MT1 gene expression in the kidneys of $\mathrm{Cd}$ treated group in comparison to control group, which comes in the same line of some authors [43] who suggested that Body defense system is extensively activated during cd exposure and normal cell releases metallothionein (MT), which help in elimination of metals because it contain high amount of cystiene. Also there was up regulation in MT1 gene expression of the group treated with zinc as mentioned by others [44] these studies mentioned the similar ability of Zn as inducer of MT expression in kidney. The activation of MT transcription factor was increased in the presence of high amount of zinc [15]. The obtained results in our experiment suggested that the combination between $\mathrm{Se}$ and $\mathrm{Zn}$ is more powerful than that of either Se or $\mathrm{Zn}$ alone in revealed Cd toxicity in kidney which agree with other finding of many authors [45-47] who mentioned that the treatment with selenium as sodium selenite in combination with another microelement as zinc can provide better protection against cadmium toxicity.

Table 4: Fold change of relative gene expression of heat shock protein ${ }_{70}\left(\mathrm{HSP}_{70}\right)$ and metallothionine (MT1) in kidney tissue

\begin{tabular}{lcc}
\hline Group & HSP $_{\mathbf{7 0}}$ & MT1 \\
\hline control & $1.07 \pm 0.02^{\mathrm{b}}$ & $1.05 \pm .03^{\mathrm{c}}$ \\
Cd & $2.032 \pm 0.06^{\mathrm{a}}$ & $2.02 \pm .05^{\mathrm{a}}$ \\
Cd\&Zn & $1.51 \pm 0.03^{\mathrm{b}}$ & $2.13 \pm .09^{\mathrm{a}}$ \\
Cd\&Se & $1.63 \pm 0.05^{\mathrm{ab}}$ & $1.64 \pm .02^{\mathrm{ab}}$ \\
Cd\&Zn\&Se & $1.46 \pm 0.07^{\mathrm{b}}$ & $1.41 \pm .04^{\mathrm{b}}$ \\
\hline
\end{tabular}

\section{Conclusion}

The present study showed that the accumulation of $\mathrm{Cd}$ in rat kidneys after dietary intake of $\mathrm{Cd}$ markedly altered the gene expression of antioxidant enzymes as (SOD, CAT and GSH-Px) and some proteins as $\left(\mathrm{HSP}_{70}\right.$ and MT1). The obtained results showed that the dietary intake of Se decreased the oxidative stress caused by $\mathrm{Cd}$ in rat kidney.
Se can alter the distribution of $\mathrm{Cd}$ in tissues and help detoxification of $\mathrm{Cd}$ by forming $\mathrm{Cd}$ $\mathrm{Se}$ complexes. $\mathrm{Zn}$ treatment also can ameliorate $\mathrm{Cd}$ induced oxidative stress in the kidney. Zn itself act as an antioxidant and helps in MT synthesis which is very important in $\mathrm{Cd}$ detoxification. Zinc and selenium ameliorate the activity of the antioxidant enzymes as (GSH-Px, SOD and CAT) and decrease HSP70 gene expression. Moreover, 
our results showed that the combination between zinc and selenium treatment has a significant role in amelioration of $\mathrm{Cd}$ induced oxidative stress in kidney of rat than either Se or $\mathrm{Zn}$ alone.

\section{Conflict of interest}

The authors declare no conflict of interest.

\section{References}

[1] Satarug, S. (2012) Long-term exposure to cadmium in food and cigarette smoke, liver effects and hepatocellular carcinoma. Curr Drug Metab, 13: 257-271.

[2] Sarwar, N.; Malhi, S.S.; Zia, M.H.; Naeem, A.; Bibi, S.; Farid, G. (2010): Role of mineral nutrition in minimizing cadmium accumulation by plants. J Sci Food Agric, 90: 925-937.

[3] Satarug, S.; Garrett, S.H.; Sens, M.A.; Sens, D.A. (2010): Cadmium, environmental exposure, and health outcomes. Environ. Health Perspect, 118: 182-190.

[4] Satarug, S.; Haswell-Elkins, M.R.; Moore, M.R. (2000) Safe levels of cadmium intake to prevent renal toxicity in human subjects. Br J Nutr, 84, 791-802.

[5] Hogervorst, J.; Plusquin, M.; Vangronsveld, J.; Nawrot, T.; Cuypers, A.; Van Hecke, E.; Roels, H.A.; Carleer, R.; Staessen, J.A. (2007) House dust as possible route of environmental exposure to cadmium and lead in the adult general population. Environ Res, 103, 30-37.

[6] Cuypers, A.; Plusquin, M.; Remans, T.; Jozefczak, M.; Keunen, E.; Gielen, H.; Opdenakker, K.; Nair, A.R.; Munters, E.; Artois, T.J.; et al. (2010) Cadmium stress: An oxidative challenge. Biometals, 23, 927-940.

[7] Droge W. (2002) Free radicals in the physiological control of cell function. Physiol Rev, 82(1):47-95.

[8] Matés M. (2000): Effects of antioxidant enzymes in the molecular control of reactive oxygen species toxicology. Toxicology,153(1-3):83-104.

[9] Klotz, L.O., Kro“ncke, K.D., Buchczyk, D.P., Sies, H., (2003) Role of copper, zinc, selenium and tellurium in the cellular defense against oxidative and nitrosative stress. J Nutr, 133, 1448S$1451 S$.

[10]Bridges, C.C.; Zalups, R.K. (2005): Molecular and ionic mimicry and the transport of toxic metals. Toxicol Appl Pharmacol, 204, 274-308.

[11] Nordberg, M.; Nordberg, G. (2000): Toxicological aspects of metallothionein. Cell Mol Biol, 46, 451-463.

[12] Amara, S.; Abdelmelek, H.; Garrel, C.; Guiraud, P.; Douki, T.; Ravanat, J.L.; Favier, A.; Sakly, M.; Ben, R.K. (2008): Preventive effect of zinc against cadmium-induced oxidative stress in the rat testis. J Reprod Dev, 54, 129-134.

[13]Valko M, Rhodes CJ, Moncol J, Izakovic M, Mazur M. (2006): Free radicals, metals and antioxidants in oxidative stress induced cancer. Chem Biol Interact, 160:1-40.

[14] Luchese, C.; Brandão, R.; de Oliveira, R.; Nogueira, C.W.; Santos, F.W. (2007): Efficacy of diphenyl diselenide against cerebral and pulmonary damage induced by cadmium in mice. Toxicol Lett, 173, 181-190.

[15]Sasakura C, Suzuki KT. (1998): Biological interaction between transition metals (Ag, $\mathrm{Cd}$ and $\mathrm{Hg}$ ) selenide/sulfide and selenoprotein P. J Inorg Biochem, 71:159-62.

[16] Nasr, I. N., Salah El-Dien, W. M. and Hend, A. M. (2007) Evaluation of some chemical pollutant levels in quail tissues. Zag Vet J, 35: 20-31.

[17]Xu Z.; Wang. Z.; Li J.; Chen C.; Zhang P.; Dong L.; Chen J.; Chen Q.; Zhang X. and Wang Z. L. (2013): Protective effects of selenium on oxidative damage and oxidative stress related gene expression in rat liver under chronic poisoning of arsenic. Food Chem Toxicol, 85: 1-7.

[18]Ding Z.; Jianfeng G.; Kerong Z.; Xiaodong L. and Jiakui L.(2012): Effects of Chronic Cadmium Poisoning on $\mathrm{Zn}$, $\mathrm{Cu}, \mathrm{Fe}, \mathrm{Ca}$, and Metallothionein in Liver 
and Kidney of Rats. Biol Trace Elem Res, 149:57-63.

[19] Livak, K. J., and Schmittgen, T. D. (2001) Analysis of relative gene expression data using real-time quantitative PCR and $2^{-\Delta \Delta \mathrm{ct}}$ method. Methods, 25, 402-408.

[20]Zabulyte, D., Paltanaviciene, A., Uleckiene, S., Kalibatas, J., Juozulyna, A., Jascaniniene, N., et al. (2007): Cadmium accumulation in the kidney and its excretion with urine, and possible influence of PAH's on these processes in rats. Bull Vet Inst Pulawy, 51:257-260.

[21] Štajn, A., Žikić, R.V., Ognjanović, B., Saičić, Z., Pavlović, S., Kostić, M., Petrović, V. (1997): Effect of cadmium and selenium on the antioxidant defense system in rat kidneys. Comp Biochem Physiol, 117C:167-172.

[22] Brzóska, M.M.; Moniuszko-Jakoniuk, J. (2001): Interactions between cadmium and zinc in the organism, Food Chem Toxicol, 39: 967-980.

[23] Bridges, C.C.; Zalups, R.K. (2005): Molecular and ionic mimicry and the transport of toxic metals. Toxicol Appl Pharmacol, 204, 274-308.

[24] Jamba, L., Nehru, B., Bansal, M. (1997): Redox modulation of selenium binding proteins by cadmium exposures in mice. Mol Cell Biochem, 177: 169-175,.

[25] Combs, G., Gray, W. (1998): Chemo preventive agents: selenium. Pharmacol Ther, 79: 179-192.

[26] Wahba, Z., Coogan, T., Rhodes, S., Waalkes, M. (1993): Protective effects of selenium on cadmium toxicity in rats Role of altered toxicokinetics and metallothionein. J Toxicol Environ Health, 38: 171-182.

[27] Uchida, M., Teranishi, H., Aoshima, K., Katoh, T., Kasuya, M., Inadera, H., (2004): Reduction of erythrocyte catalase and superoxide dismutase activities in male in habitants of a cadmium-polluted area in Jinzu river basin. Japan Toxicol Lett, 151 (3), 451-457.
[28] Hussain, T., Shukla, G.S., Chandra, S.V. (1987): Effects of cadmium on superoxide dismutase and lipid peroxidation in liver and kidney of growing rats: in vivo and in vitro studies. Pharmacol Toxicol, 60 (5), 355-358.

[29]Bauer, R., Demeter, I., Hasemann, V., Johansen, J.T. (1980): Structural properties of the zinc site in $\mathrm{Cu}, \mathrm{Zn}$ superoxidedismutase; perturbed angular correlation of gamma ray spectroscopy on the $\mathrm{Cu}, \quad 111 \mathrm{Cd}-$ superoxidedismutasederivative. Biochem Biophys Res Commun, 94 (4), 12961302.

[30] Jemai, H., Messaoudi, I., Chaouch, A., Kerkeni, A. (2007): Protective effect of zinc supplementation on blood antioxidant defense system in rats exposed to cadmium. J Trace Elem Med Biol, 21 (4), 269-273.

[31]Jihen, E.H., Imed, M., Fatima, H., Abdelhamid, K. (2008): Protective effects of selenium (Se) and zinc ( $\mathrm{Zn}$ ) on cadmium $(\mathrm{Cd})$ toxicity in the liver and kidney of the rat: histology and $\mathrm{Cd}$ accumulation. Food Chem Toxicol, 46, 3522-3527.

[32]Ognjanovic', B.I., Markovic' , S.D., Pavlovic' , S.Z., Zikic'R.V., Stajn,A.S., Saicic' , Z.S. (2008): Effect of chronic cadmium exposure on antioxidant defense system in some tissues of rats: protective effect of selenium. Physiol Res, 57(3),403-411.

[33] Lazarus, M., Orct, T., Blanusa, M., Kostial, K., Pirsljin, J., Beer-Ljubic, B., (2006): Effect of selenium pre-treatment on cadmium content and enzymatic antioxidants in tissues of suckling rat. Toxicol Lett, 164, S191.

:[34] Gambhir, J., Nath, R. (1992): Effect of cadmium on tissue glutathione and glutathione peroxidase in rats. Influence of selenium supplementation. Indian $\mathbf{J}$ Exp Biol, 30, 597-601.

[35] Waisberg, M., Joseph, P., Hale, B. and Beyersmann, D. (2003): Molecular and cellular mechanisms of cadmium carcinogenesis, Toxicology, 192: 95-117. 
[36] Jamba, L., Nehru, B., Bansal, M.P., (2000): Effect of selenium supplementation on the influence of cadmium on glutathione and glutathione peroxidase system in mouse liver. J Trace Elem Exp Med, 13, 299-304.

[37] Kojima-Yuasa, A.; Umeda, K.; Olikita, T.; Kennedy, D.O.; Nishiguchi, S.; Matsui-Yuasa, I (2005): Role of reactive oxygen species in zinc deficiencyinduced hepatic stellate cell activation. Free Radic Biol Med, 39, 631-640.

[38] Jurczuk, M., Brzo' ska, M.M., Moniuszko-Jakoniuk, J., Ga"azynSidorczuk, M., Kulikowska-Karpin's ska, E. (2004): Antioxidant enzymes activity and lipid peroxidation in liver and kidney of rats exposed to cadmium and ethanol. Food Chem Toxicol, 42 (3), 429-438.

[39] Khan, S., Khan, M.A., Bhatnagar, D., Yadav, D., Sarkar, S.C. (1991): Zinc protection against lipid peroxidation from cadmium. Indian $\mathbf{J}$ Exp Biol, 29:823-5.

[40] Giffard, R.G., Xu, L., Zhao, H., Carrico, W., Ouyang, Y., Qiao, Y., Sapolsky, R., Steinberg, G., Hu, B., Yenari, M,A. (2004). Chaperones, protein aggregation, and brain protection from hypoxic/ischemic injury. J Exp Biol, 207: 3213-3220.

[41] Han, S.G., Castranova, V., Vallyathan, V. (2007) Comparative cytotoxicity of cadmium and mercury in a human bronchial epithelial cell line (BEAS-2B) and its role in oxidative stress and induction of heat shock protein 70 . J Toxicol Environ Health, Part A., 70: 852-860.
[42] Brzo’ ska, M.M., Galaz yn-Sidorczuk, M., Rogalska, J., Roszczenko, A., Jurczuk, M., Majewska, K., MoniuszkoJakoniuk, J., (2008). Beneficial effect of zinc supple- mentation on biomechanical properties of femoral distalend and femoral diaphysis of malerats chronically exposed to cadmium. Chem Biol Interact, 171,312-324.

[43] Pacher, P.; Beckman, J.S.; Liaudet, L. (2007) Nitric oxide and peroxynitrite in health and disease.Physiol Rev, 87, 315424.

[44] Tandon, S.K.; Singh, S.; Prasad, S.; Mathur, N. (2001): Hepatic and renal metallo thionein induction by an oral equimolar dose of zinc, cadmium or mercury in mice. Food Chem Toxicol, 40 571-577.

[45] Xiao, P., Jia, X.D., Zhong, W.J., Jin, X.P., Nordberg, G., (2002). Restorative effects of zinc and selenium on cadmiuminduced kidney oxidative damage in rats. Biomed Environ Sci, 5 (1), 67-74.

[46] Heni, J., Messaoudi, I., Hamouda, F., Kerkeni, A. (2008): Protective effects of selenium (Se) and zinc ( $\mathrm{Zn}$ ) on cadmium (Cd) toxicity in the liver and kidney of the rat: histology and $\mathrm{Cd}$ accumulation. Food Chem Toxicol; 46:3522-7.

[47] Messaoudi, I., El Heni, J., Hammouda, F., Saïd, K., Kerkeni, A. (2009): Protective effects of selenium, zinc or their combination on cadmium-induced oxidative stress in rat kidney. Biol Trace Elem Res, 130:152-61 


\section{الملخص العربي}

تأتير الزنك والسيلينيوم والامج بينهما على الاجهاد التأكسدى الناتج من التعرض للكادميوم فى كلى الفئران- دراسة جزيئية صفاء خاطر، حمد السعداوي و شروق النان من البسيوني

$$
\text { قسم الكيمياء الحيوية_كلية الطب البيطري- جامعة الزقازيق }
$$

يعتبر الكادميوم واحدا من اكثر ملوثات البيئة سمية حيث ينتقل خلال كثير ا من السلاسل الغذائية. ويعتبر الزنلك و السيلينيوم

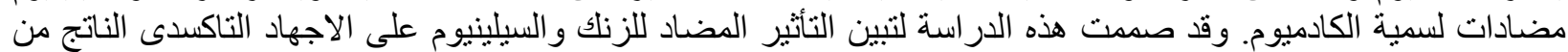

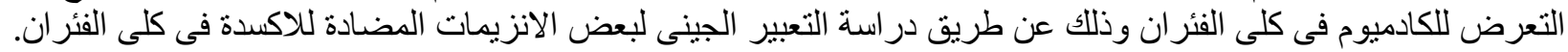

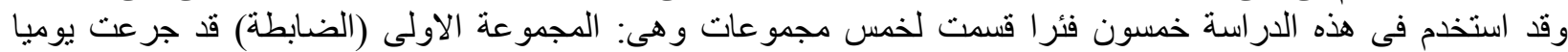

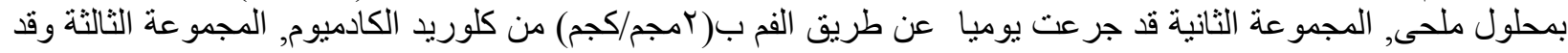

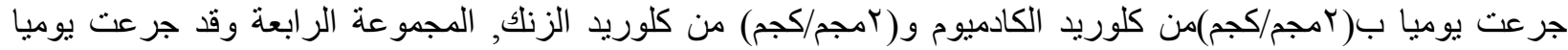

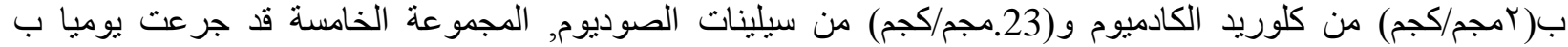

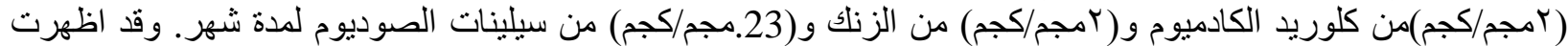

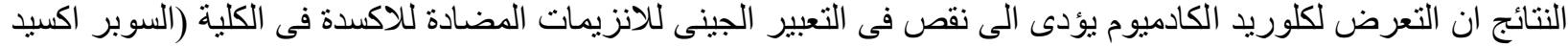

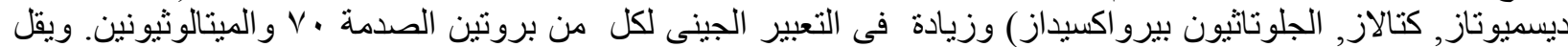

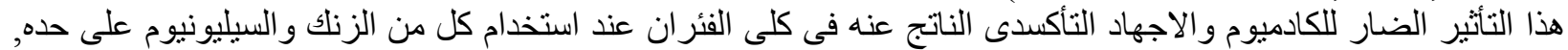

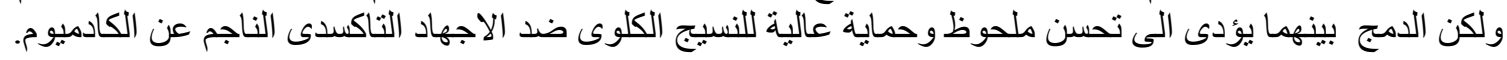

